\title{
Paternally-Expressed Gene 3 Protein
}

National Cancer Institute

\section{Source}

National Cancer Institute. Paternally-Expressed Gene 3 Protein. NCI Thesaurus. Code C112872.

Paternally-expressed gene 3 protein (1588 aa, $181 \mathrm{kDa}$ ) is encoded by the human PEG3 gene. This protein is involved in both tumor suppression and the regulation of apoptosis. 